\title{
Communities and knowledge production in archaeology
}

Julia Roberts, Kathleen Sheppard, UIf R. Hansson and Jonathan R. Trigg (eds)
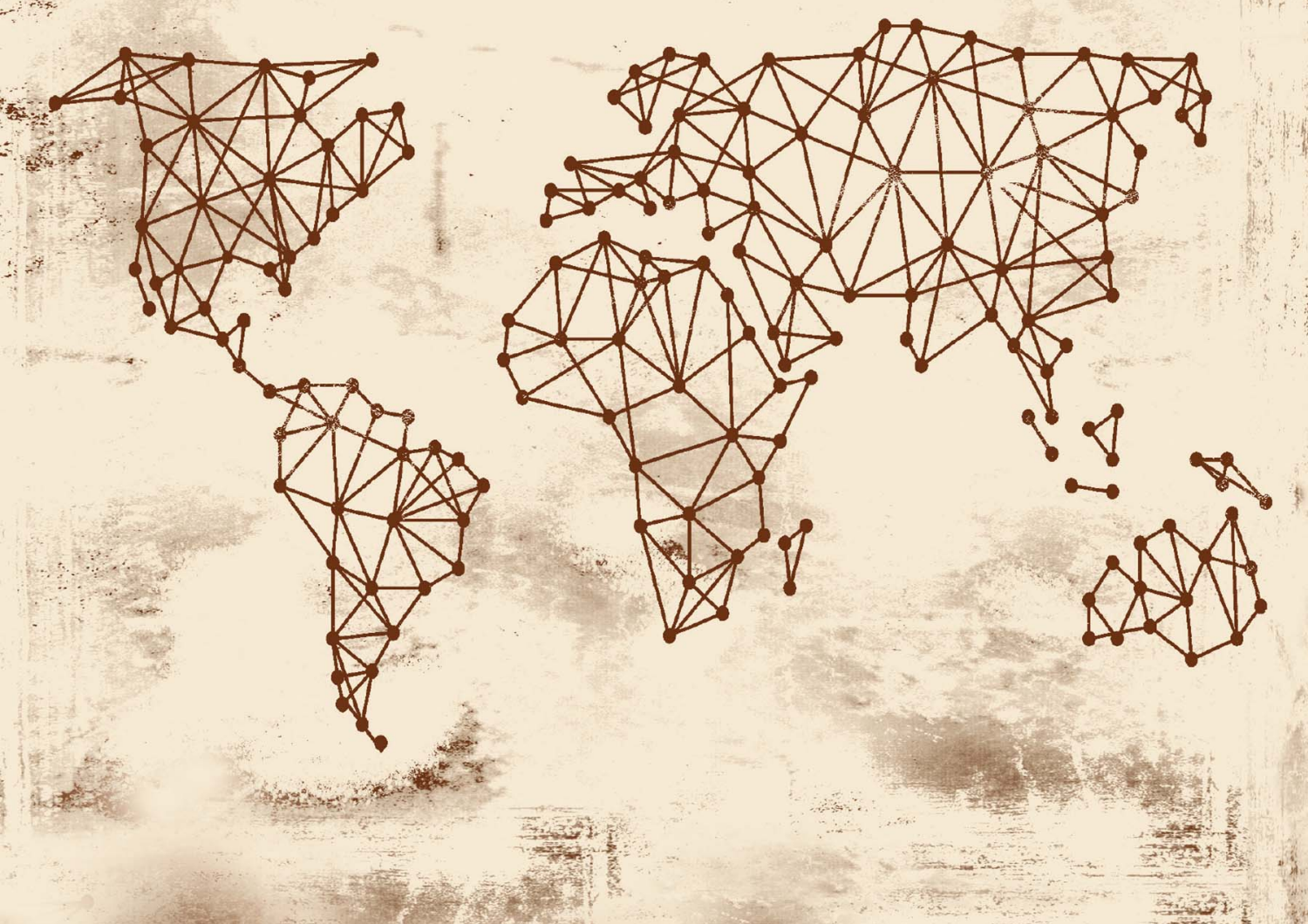


\section{Communities and knowledge production in archaeology}

\section{MANCHESTER 1824}

Manchester University Press 


\title{
Social Archaeology and Material Worlds
}

\author{
Series editors \\ Joshua Pollard and Duncan Sayer
}

Social Archaeology and Material Worlds aims to forefront dynamic and cutting-edge social approaches to archaeology. It brings together volumes about past people, social and material relations and landscape as explored through an archaeological lens. Topics covered may include memory, performance, identity, gender, life course, communities, materiality, landscape and archaeological politics and ethnography. The temporal scope runs from prehistory to the recent past, while the series' geographical scope is global. Books in this series bring innovative, interpretive approaches to important social questions within archaeology. Interdisciplinary methods which use up-to-date science, history or both, in combination with good theoretical insight, are encouraged. The series aims to publish research monographs and well-focused edited volumes that explore dynamic and complex questions, the why, how and who of archaeological research.

\section{Previously published \\ Neolithic cave burials: Agency, structure and environment Rick Peterson}

The Irish tower house: Society, economy and environment, c. 1300-1650 Victoria L. McAlister

An archaeology of lunacy: Managing madness in early nineteenth-century asylums

Katherine Fennelly

Forthcoming

Images in the making: Art, process, archaeology

Ing-Marie Back Danielsson and Andrew Meirion Jones (eds)

Early Anglo-Saxon cemeteries: Kinship, community and mortuary space Duncan Sayer

$$
\begin{gathered}
\text { Urban Zooarchaeology } \\
\text { James Morris }
\end{gathered}
$$

An archaeology of innovation: Approaching social and technological change in human society

Catherine J. Frieman 


\section{Communities and knowledge production in archaeology}

Edited by Julia Roberts, Kathleen Sheppard,
UIf R. Hansson and Jonathan R. Trigg

Manchester University Press 
While copyright in the volume as a whole is vested in Manchester University Press, copyright in individual chapters belongs to their respective authors.

An electronic version of this book is also available under a Creative Commons (CC-BYNC-ND) licence, thanks to the support of Knowledge Unlatched, which permits noncommercial use, distribution and reproduction provided the editor(s), chapter author(s) and Manchester University Press are fully cited and no modifications or adaptations are made. Details of the licence can be viewed at https://creativecommons.org/licenses/by-nc-nd/4.0/

Published by Manchester University Press

Altrincham Street, Manchester M1 7JA

www.manchesteruniversitypress.co.uk

British Library Cataloguing-in-Publication Data

A catalogue record for this book is available from the British Library

ISBN 9781526134554 hardback

ISBN 9781526134561 open access

First published 2020

The publisher has no responsibility for the persistence or accuracy of URLs for any external or third-party internet websites referred to in this book, and does not guarantee that any content on such websites is, or will remain, accurate or appropriate.

Typeset in 10.5/12.5 Sabon LT Std by

Servis Filmsetting Ltd, Stockport, Cheshire 